\title{
The Quest for Algerian Linguistic Independence
}

\author{
Abdelhamid Bessaid \\ Department of English Language, Faculty of Foreign Languages \\ King Khalid University, Abha \\ Kingdom of Saudi Arabia
}

\begin{abstract}
The paper focuses on the eternal conflict between the existing languages in Algeria as a whole, starting from Berber language varieties through Tamazight to Arabic, then French, and the struggling issue in the Algerian linguistic network. It also examines the existing relationship between the patterns of Arabic language in Algeria, since it was considered as a foreign language until 1947, chiefly through, highlighting the relationship between Classical Arabic among Algerian society, and the language policy (Arabization) pursued since wrenching independence and the linguistic repercussions of the colonization period on Algerian Arabic. In this respect, among other findings, a foremost issue raised to highlight such a critical phenomenon; and that later leads to question the different realities between the Algerian National Constitution and daily practices among users. In other words, the new generation speakers face a natural barrier communicating with post-independence schooled generation. In this sense, the former represents the 'Arabization' policy pursued in Algeria; whereas, the latter is 'francophone,' considering the linguistic as well as the sociolinguistic repercussions that might outcome such contact in a country famed by the use of French among its diplomats as a language of instruction and discourse, whether as a formal discourse or informal speech. The research methodology is based on early retrospect works to denote such cross- conflicting status raised as a significant issue. Finally, the study recommended a siné- qua- non question which is, when will Algerians put an end to the different linguistic situations inherited after gaining their political independence in 1962 ?

Keywords: Algerian Arabic, Arabization, Berber, French, language conflict, language contact, language heterogeneity, Maghreb language matters, Tamazight

Cite as: Bessaid, A. (2020). The Quest for Algerian Linguistic Independence. Arab World English Journal for Translation \& Literary Studies 4 (2) 105-119.

DOI: http://dx.doi.org/10.24093/awejtls/vol4no2.8
\end{abstract}




\section{Introduction}

To establish plausible diagnostics about the actual conflicting linguistic quarrel in Algeria; the writer scrutinizes the Algerian linguistic issue which had been influenced by a bulk number of factors that the author considers them as the critical hinges behind the complexity of the linguistic situation; some of which are historical, others are political, and sociocultural. It is crystal clear that they were as logical repercussions of the various past events experienced by the country. To note, Algeria is located in North Africa between Morocco and Tunisia to which it shares collective geographical borders, and mainly a shared past of French colonial governance. The Algerian society acquired/ developed a different identity that is characterized by some linguistic variables, and which could be observed through comparing language use/ usage among Algerians and the neighboring countries; Morocco and Tunisia, which encountered the same historical stages, but for a shorter period. To be colonized for 132 years, that lasted from (1830-1962) by France, made the French colonizer considers Algeria as a French colony. The researcher goes through the main stages of the linguistic clash(s) that made Algeria a melting pot language network as a result of the French policy in Algeria, there was a similar influence on different sectors, including education in particular, in addition to administrative affairs, trade, and government.

Despite the resistance of the principles of colonialism, the French language and culture's resonances were keen on the Algerians resulting in a type of dual identity. This influence is patent through the conflict that appears when two or more languages are used. The reason that prompts the writer to shed light on language duality, and what results as code-switching, code- mixing, borrowing, and diglossia.

\section{Language Contact in Algeria}

\section{Modern Classical Arabic and Algerian Arabic: A Heterogeneous Channel}

There are four forms of Arabic language in the Arab world: Classical Arabic (CA), Modern Standard Arabic (M.S.A.), the Elite's Arabic (a kind of 'pure' Arabic) used among intellectual people, and dialectal Arabic. The combination of these linguistic forms led to the overlap with extra/ extraneous factors, which themselves gave a new term called 'Disorientation linguistic deficiency/ handicap.' These figures put altogether give a scholar an image of the difficulty of describing the language panorama in Algeria. The fact that illustrates the complexity of endorsing linguistic boundaries to use Arabic in a society characterized by taking a hefty dose of French since its birth. Bouhadiba (1998) points out in this issue; 'la réalité linguistique actuelle telle qu'elle se présente à l'observation est caractérisée par un continuum de l'arabe ou les variétés de cette langue sont parfois difficiles à délimiter Arabe classique, Arabe littéraire, Arabe standard moderne ; Arabe parlé cultivée, variétés dialectales à dosage arabe mais le français fortement implanté au niveau lexical'. (p.12).

(The current linguistic reality as is presented to observation had been characterized by a continuum of Arabic where the varieties of this language are sometimes tricky to delimit to Classical Arabic, literary Arabic, Modern Standard Arabic; elites spoke Arabic; dialectal types had an amount of Arabic, but French is firmly established at the lexical level).

Therefore, it is worth arguing that the researcher of this case finds difficulty in applying the principles of diglossia to the linguistic reality in Algeria, and it remains mysterious unless 
including some examples of the TV discourses, or religious sermons in the mosques where the speaker switches from 'High' to 'Low' variety to convey his message to the largest majority audience, including those who are not educated. In contrast to the written form in Arabic, most of the modern and juridical literacy writings, and academic lectures are written in classical Arabic. Loyer (1987) assumes : "Ou bien la langue imposée va substituer lentement mais surement à la langue dominée ; ou bien les usagers de celle-ci vont œuvrer à sa normalisation (C'est à dire à une utilisation normée dans tous les domaines de la communication) en combattant les tendances à l'assimilation" (p. 18).

(Either the imposed language will slowly replace it, but surely to the dominated style, or the users of this language will work on its normalization (i.e., towards a standardized use in all communication domains) fighting the assimilation tendencies).

However, after independence, and especially after the 1990s, there was a bias towards the Arabic vocabulary at the expense of French language, including; 'tablier, équerre, compas, gomme, taille-crayon, cahier, etc.' These French words were replaced by Arabic vocabulary in daily use,

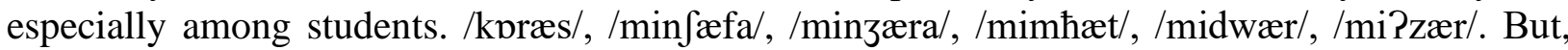
nobody fails to notice that the word 'school bag' in Arabic/mihfaḍ/ is still used in French $/ \kappa \alpha\rceil \tau \alpha \beta \lambda /$ 'cartable'. Nonetheless, it is noticed that the Arabic vocabulary has begun to dominate and take the place of the French vocabulary and phrases in Algerian daily uses, including but not limited to, for example, the phrase 'Good night' in Arabic that is said /leilæ $\left.\sigma \alpha \aleph_{1}\right\rceil \delta \alpha /$ replaces the French expression 'Bonne nuit,' the word 'daily' in Arabic/jawmijæn/ instead of the French one 'quotidiennement'. However, people can still hear many French vocabulary and expressions in Algerian daily Arabic, and which seems to last at least for a while.

\section{The Algerian Dialect and the French Language}

The relationship between the Arabic language and its French counterpart in Algeria is chiefly attributed to the length of the colonial era. The consequent fall of the latter in the Algerian daily use is either through the use of Arabic or Berber depending on the speaker's ethnic belonging on the one hand, and his engagement for the technologically developed world and various scientific fields, and then French language as a criterion for development on the other hand. Almost, you hardly hear an Algerian uttering/ formulating utterance free from French words. Bouhadiba (1998) asserts in this context: "A great number of French borrowings, both adapted and non-adapted, can frequently attest in everyday speech, particularly in urban areas where French got to hold more firmly than in rural ones. The Algerian society has so deeply been influenced by French that we virtually cannot hear a conversation without at least a few French lexical items or expressions"

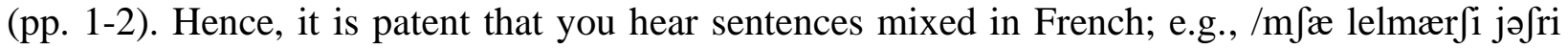
demp w vera:(n)/ [He went to the market to buy a receiver and a converter]. Besides, as already stated, the colonial era had a prominent effect on the daily uses as you might find ready-to-use phrases like 'C'est OK, c'est fait? Ça y'est? C'est fini? Questions likewise had corresponding retrospective answers mixed with French language expressions like 'ça va hamdolilah' [Ok, thanks to God].

\section{French Colonialism Impact}

Arab World English Journal for Translation \& Literary Studies 
French colonialism did not only affect language and culture in Algeria, but it went beyond that to change the doctrine of the French colonial policy and rules (assimilation concept of repentance), where independence was seen to train and get used to the French culture by intellectuals; however, it remained a traditional life-pattern. Despite this apparent difference mainly in West Africa, there was a form in the use of similar words by the French authorities in Algeria in the 1850s. Prince Napoleon Jerome, who did not visit Algeria before, approved the absorption of the entire Muslim population. Hobsbawm (1990) reveals: "we are confronted by a hardy perennial, a strongly rooted national identity which must be eradicated by assimilation". (p.3).

In contrast, in the early years of French colonization to Algeria, the eyes were addressed to the repression of the country's culture rather than the consolidation of French culture for Algerians. Gordon states that the percentage of education at the beginning of colonialism was between $40 \%$ and 50\%, and this does not mean that there were newspapers or means to teach Quran. On the contrary, it was traditional. A French source, De Reynard, the founder of the 'Arab Bureaus' (Les Bureaux Arabes) affirms (1836):

Education in Algeria was not different from that spread in France. Tocqueville (1847) claims in this respect:

"we have cut down the number of charities, let schools fall into ruin, closed the colleges. Around us, the lights have gone out, the recruitment of men of religion and men of law has ceased. We have, in other words, made Muslim society far more miserable, disorganized and brutal than ever was before it knew us" (p.4).

After the Republic Revolution in 1848, Algeria became a part of France with the French language inauguration as an official language as France stopped subsidies and donations, endowments, or 'Habbous' (Islamic Religious Affairs) which was the source of financial support for education including the Arabic language. Consequently, without this support, the educational system collapsed.

In fact, 'Assimilation' meant many things in both France and Algeria; in France, it meant; the expansion of the rights and privileges of the Arabs with equal rights with the French citizens. Ageron (1991) comments:

"Assimilation in Algeria was designed not only to give the French their full share of privilege but to create what Lyautey later called 'overblown or super-citizens,' with rights in exes.... This fundamental mistake as to the true meaning of assimilation in the country lasted throughout the whole history of French in Algeria" (pp. 48-49).

In Algeria, instead of treating Muslims as French, the analogy came to mean the passage of the indigent 'law of indigenous' (Code de l'indigénat) in 1881, which introduced a special law for such category of people to reach adoption of sanctions including imprisonment without a trial.

The policy of attacking the structure and the foundation of the Algerian society began with the division of large families and the creation of a cease-fire with military tribes by the end of 
1870, and that was through the establishment of an Islamic legal regime that was administratively affiliated to the French Judiciary. Moreover, the scholars continued administratively to eliminate 'French Medersas' (French schools). The French administration was seeking to resist active forces in the clergy. The same relationship between the church and the state was contrary to the French law, which separated the two in 1905. On the contrary, the code was used to persecute the civil Muslims and then the Arabic language. In this respect Patai conveys; 'In the Kabyle area,' a policy of divide and rule was installed, only allowing education in French schools and closing all Quranic ones. Some even went so far as to justify this by claiming that the Kabyles were descendants of the Gauls. The policy of segregation of education had left the state in a complicated relationship with the majority of the population. Then it knew the culture of 'the core of one's identity'. But France became the French national identity tool in its broad sense, although some ethnic tribes denied this, and this was not the case in Algeria that was under the policy conducted by the Frenchspeaking ethnic tribes. In the meantime, there was a gap expanding between the European economy and the Muslim one. Such a fact represented the essential components of the development of the Algerian identity. Minogue (1967) points out: 'It is a political movement depending on a feeling of collective grievance against foreigners'. (pp. 25-26). Holt (1990) adds,

'Nationalism represents the common interest against particular interest and the common good against privilege. He claims that the masses are usually the last group to be affected by nationalism. Such was the case in Algeria, the general discontent generated by deteriorating economic position, the sense of outrage caused by all was to view privilege and the feeling of cultural alienations that were channeled in the 1920-s and 1930s into specific nationalist ideologies by different prominent intellectuals and scholars' (p. 32).

However, they had been convinced that the majority in Algeria speak Arabic or Berber. It was vital for them to be confident that Classical Arabic; the language of Islam and symbol of the nation, became easy through:

a- The French government's confession of the emergence of the Algerian state as Muslims, Arabs, Berbers and the establishment of an exclusion policy which excluded them from economic benefit of the modern state, then exclude them from the educational, and judicial system through issuing the feudal law that was; however, based on language and religion.

b- Politicians' belief of the big habit and which give legitimacy and credibility of those nationalists demanding originality of the language and culture; Islam's message and holly book is in Arabic, and consequently whatever authority and law were written in Arabic, and this helps to perform/apply the task; the more the habit is large, the easier the mission is.

c- Muslims in the cities gave great impetus to literary writings in the sense that the linguistic issue in Algeria was politicized in contemporary history. The Arabic language was used as an umbrella of national identity. It is a fashion, at least for those days, to talk about sovereignty, which means convincing and not forcing the masses to follow the elite's ideology. In the history of official languages of this matter, it means to convince people that the tone of the elite is the most appropriate and must be considered as an official language. 
Nowadays, we can quickly note that French still has its privilege in Algeria. Saad (1992) confesses,

"French continues to enjoy a privileged position in all three countries of the Maghreb despite governmental Arabization Programs. Massive numbers still speak French. In fact, "twenty times more children learn French than during the time of French Algeria.... Algeria is the second most francophone nation in the world". (p, 22).

\section{From Berber to French through Arabic}

Three significant historical periods marked Algerian linguistic history. The first one witnessed the Berber presence and dominance on the whole Algerian land. The conquest of the Arabs to North Africa marked the second period, and the last period is that one known by the French invasion and the introduction of the French language.

\section{Berber}

Before the coming of the Arabs to North Africa in the $7^{\text {th }}$ century, the Berbers were dominating the area from the Atlantic to Egypt. Galand (2010) declares that: "Avant l'arrivée des Arabes en Afrique du Nord (7éme siècle), le Bérber occupait un domaine d'un seul tenant, de l'Atlantique à l'Egypte', (p. 9).

(Before the coming of the Arabs to North Africa ( $7^{\text {th }}$ Century), the Berbers occupied the area in one piece; from the Atlantic to Egypt).

The Arab invasions and propaganda of the Arabic language led to radical changes to the linguistic situation in this region of the world. For some centuries, Arabic did not reach to replace Berber, and mainly Tamazight varieties in the north of Algeria. But, today, 25\% of the Algerian population learn and exercise Tamazight (about 9.5 million inhabitants out of 42) distributed throughout Algeria. In the eastern part of Kabyle, in the west of Algiers, and the capital city of 'Chenaoua,' Algiers, Beni- Mezab in the southwest, Awras, and in many other parts of the west of Algeria; Ain Safra. This unfair distribution of Berber dialects affected communication between speakers of these dialects across Algeria's vast borders consequently. Such widespread existence prompts the Algerian government recognizes Tamazight as a second national language. In the same vein, a Kabyle responded to aspects of Arabization of the country in Saad's thesis (1992):

'.... . Donc objectivement parlant, je crois qu'il faut laisser la langue française comme langue d'instruction scientifique et l'arabe comme langue littéraire car cette dernière accuse un retard d'un siècle et demi par rapport à la science (excusez-moi si j'exagère). En accusant un retard, elle nous induit nous aussi au retard. Ne dites pas que je suis néo-colonialisé (je pense que je suis objectif) ! Je pense qu'il faut supprimer cette idéologie de langue étrangère ou bien de colons, car elle nous sert beaucoup. Mais à ce que je vois, l'introduction de l'arabisation n'est pas réfléchie car elle est introduite seulement pour refléter l'identité algérienne.' (pp. 143-144).

(Objectively speaking, therefore I think that French should remain the language of science instruction and Arabic a literary language because the latter is one and a half centuries behind visà-vis science (excuse me if I am exaggerating). Because of this delay, we in turn, are left behind. 
Do not say that I am neo-colonized (I think that I am objective)! I think we have to get rid of this ideology of foreign language or language of the settlers because French is very useful to us. However, according to what I see, the introduction of Arabization has not been thought out carefully. It has only been introduced to reflect Algerian identity).

\section{Arabic}

Algeria was established at the time of the Arab tribes in North Africa. All of this explains how the deployment of the language in space and time was decisive as it gradually led to the localization of Arabic throughout the country. However, it is not for granted that all Algerians believe that Arabic would be a good fit for science, research, and technological development of the country. Saad (1992) presumes on the words of an Algerian Kabyle who responded to her question about his attitude towards Arabic in Algeria:

'Je pense que l'arabe n'a pas connu d'histoire dans le domaine de la science (manque de documents, traduction difficile). Bien qu'on parle d'Ibn Sina et de ses compagnons, je crois qu'ils sont dépassés et que le monde est bouleversèe (avec les techniques nouvelles). C'est pour cela que je me demande si on arabise dans le but que les autres disent que nous sommes arabes ou bien pour freiner le development '. (pp. 100-101).

(I think that Arabic did not have a history in scientific research; (lack of documents, difficult translation). Although we talk of Avicenna and his companions, I think that they are outdated and that the world has been revolutionized through new technologies. That is why I wonder whether we Arabize, so others think of us Arabs or somehow to halt development).

In the same vein, a great majority of the Algerian population agree that Arabic should be left for religious affairs, and must be remoted from the scientific spheres. An Algerian responding Saad (1992) in her questionnaire about the Arabic language and Arabization;

'L'arabisation ne peut toucher aux domaines technologiques, pas pour le moment du moins. Si on compare notre pays à l'Egypte ou à l'Arabie Saoudite, pays plus développés que nous en arabe, [on trouve que] les matières techniques y sont enseignées en anglais' (p. 106).

(Technological domains cannot be arabized, at least not in the near future. If we compare our country to Egypt or Saudi Arabia, where Arabic is more developed, [we find that] technical subjects are taught in English).

Surprisingly, you can note and feel in certain Algerian areas 'la haine' / hate towards Arabic as a language which does not reflect the Algerian identity. Saad (1992) comments through a respondent to her questionnaire: “... je pense que l'arabe ne reflète pas l'identité algérienne” (p. $101)$.

(... I think that Arabic does not reflect the Algerian identity). 


\section{French}

The establishment of French and later its position as the language of power during the French colonial period (1830-1962), then the introduction of French as the language of education, business, and job opportunities reduced the presence of Arabic in many areas. Gordon (1966)-notes in this respect:

'The quest for cultural independence involves both a return to an alienated identity and the fulfillment of a personality in large part molded by the colonial experience itself. This double aspiration ... is particularly complex for the Algerians. This is so because Algeria's alienation has been so great, and on the level of her elite, she has moved so far into the culture of the colonial power and into the culture of the modern west' (p. 161).

Weinstein; (1983) consolidates the same view through the Arabization movement initiated in Algeria since early independence:

"Arabization had progressed only at the expense of the powerless, namely ... the poor Arabs and Berbers. University students coming from poor rural families without much prior exposure to French, go into Arabic medium classes of the university instead of the French or Bilingual stream ...." (pp. 122-123).

Once either poor Arabs or Berbers receive their university degree, they find that they cannot get the best jobs or even hope to get them eventually because French is still the language of administration. In the same vein, French, spread to all areas of public life to be, even the official language. Saad (1992) adds: 'The conflict between French and Arabic in the workplace is perceived as having access to better jobs than their Arabophone colleagues. Most have been obliged to teach Arabic courses. (p.8).

In an article in the French periodical Le français dans le monde, Akouaous (1984) writes:

"La tension qui domine les rapports entre le français et l'arabe risque encore de durer et, à moins d'une planification linguistique plus cohérente, l'équilibre ne sera pas atteint tant que les contradictions qui pèsent sur l'institution scolaire (car la langue, c'est aussi une façon de voir, de penser, d'agir) persisteront" (p. 28).

(The tension which dominates the relations between French and Arabic may last a long time and, barring more coherent language planning, a balance will not be reached as long as the contradictions which weigh on the school institutions (because language is also a way of looking at things, of thinking, of acting) persist).

Moreover, the French language had a 'bad' influence on the cultural identity of Algerians; a Kabyle remarks: ' Ils disent que le français entrâine une perte de l'identité culturelle, que l'Algérie ne sera vrâiment indépendante qu'une fois que l'arabe aura repris sa place de la langue première du pays'.

(They say that French language use leads to a loss of cultural identity, that Algeria would not be independent until Arabic regains its place as the first language of the country) 
Saad (1992) adds in this respect; Abdelmadjid Medarci, (1987) another French-educated sociologist complained about his feeling as being alienated because he was an Arabophone and he considered the French language as a relic of colonialism.

' On nous somme, en quelque sorte, de nous déclarer étrangers à notre pays ... je conteste formellement quiconque m'interpelle sur le plan du patriotisme, l'Algérie c'est aussi moi, cadre formé dans une école française, cela je n'y peux rien'. (p.8).

(We are summoned, as it were, to declare ourselves strangers in our own country .... I formally refuse anyone the right to question my patriotism, Algeria is also me, elite educated in a French school; that, I cannot help).

\section{Meaning of Arabization}

The policy of Arabization consists of two spheres; a national language that must meet a double change, and that must supplant the French language, and revitalize the cultural personality. Moreover, it is necessary to solve the change and replace the multilingual dialects in a unified style. From these two perspectives, just the first one was evident, but the reactions against the Arabization policy showed that the existence of the second was conscious. The preparation of a national language was born of classical Arabic. The only legacy claimed is that the Arabic of the Quran allows the state to deliver the source of establishing the original proportions that Islam must bring to the nation. However, this view was constrained by modernization industry, which was featured by positives in return for reasons of modernity that was against the nature of the country, and for that reason the policy of Arabization was considered as contradictory reconciliation; the reform of Islamic personality and assuring the change of the nation in the sense that it will be opened on different cultures and other values.

In the three countries of the Maghreb, Arabization policies have been introduced to shape and change all that was in the French language into Arabic, in education, management, and public life. Successive governments until the 1980s implemented a policy of balancing the two poles. The first argues that Arabic is the language of Islam, honesty, the mother tongue of the nation. Muslim reformers supported this position. The second, which praised the elimination of any language that disrupts the progress and development of the country. Permanent oscillations between the two poles identified in each country through a highlighted 'crisis' and alerted the unfortunate reality of education. It is the case of Morocco in 1966, Tunisia in 1969, and lately, Algeria in 1977. Ibrahimi (1995) reveals this issue :

'L'arabisation n'est pas l'islamisation. Elle est prononcée en 1962 par le président Ahmed Benbella pour préciser que la politique d'arabisation n'a pas pour but l'islamisation du pays.... La même expression fut utilisée au début des années 1980 par un ministre algérien des affaires religieuses, pour dire que l'arabisation, pour satisfaire les milieux religieux, devait prendre en charge l'Islamisation : une déclaration à l'attention des Islamisants' (p. 87).

(Arabization does not intend to mean 'Islamization'. An expression pronounced by President Ahmed Benbella in 1962 to clarify that Arabization policy, which is not aimed at the Islamization of the country.... The same feeling was used in the early 1980s by an 
Algerian minister of religious affairs, to say that Arabization, is to satisfy religious milieu, had to take in charge Islamization: a declaration for the attention of Islamists).

Moreover, AA is influenced by many languages of the colonizers who colonized Algeria across the history; the Berber, the Turk, the Arab, the Andalusian, and the French. The Algerian Arabic is characterized by some differences that might appear between speakers from different regions; so that we can note 'Dziri Arabic' that belongs to the capital Algiers, and that was influenced by the Turks, and the 'Orani Arabic' represented by words from Zenate origins, 'Tlemceni Arabic' and 'Nedroumi Arabic' which is derived from Andalusi Arabs, and 'Mostaganemi Arabic' characterized by the use of many Jewish-Arabic words. These language varieties found and used in the Algerian speech network do not present any linguistic obstacles by any linguistic intelligibility between those speakers. By contrast, it helps to know the geographical location of the speaker, and for that reason, we find most Arabs, mainly in the Middle East, encounter difficulties in deciphering the Algerian Arabic.

\section{Movement of Arabization Policies in Algeria}

On the whole, the researcher can distinguish four periods in the linguistic policy of the Algerian rulers. Nonetheless, Arabization in Algeria, as seen by Berrabah (2007), "... had to be implemented with great care because of the many obstacles that lay ahead of it" (p. 235). The phase of President Benbella (1962-1965), the period of the successor, President Boumédiene (1965-1978), the stage of President Chadli (1979-1988), and the phase of President Bouteflika (1999-2019). Although some marked the openness of President Bouteflika on foreign languages, especially English, with the preservation of Arabic language as the national and official language. Whatever the period is taken, it must be understood that 'the Arabization Movement' has intended to accelerate or halt the spread of Arabic! Furthermore, this policy tended to widen the sociocultural sphere towards Arabization. Then this movement clashed with other economic, professional, pedagogical realities. Lately, the concept of 'Arabization' was still a new alien term that aimed to assure the school entry for fall 1962.

The following period (1965-1978) is known as the second stage of Arabization; that is, the establishment of a system to measure, and take into consideration the Arabization process and the management of the order of imposing such regulations. During that period, the Cultural Revolution Center was considered as the pivot hinge for Arabization regarding the confrontations witnessed in the political sphere between supporters and opponents, and between rapid and extensive Arabization of the administration and the educational system on the one hand, and between the minister of culture (1977-1979) Mustapha Al- Ashraf, who called for restraint, and Arabization far away from the low status of education, from another hand. The year that followed the death of President Boumediéne in December 1978, there were political confrontations within the government about the linguistic policy defended by Mustapha Al Ashraf to rethink the Arabization policy met with opposition that was sent out again lately by the successive government. The period lasted from (1980-1988) witnessed a new system characterized by the recognition of Tamazight, and the French language to a limited extent.

Arab World English Journal for Translation \& Literary Studies 
Since independence, Algeria had engaged in Arabization policy in the administrative, and educational system of the country. This situation declared that Arabic was the national language in 1962, and Arabic as the official language in 1963. This status gave to Arabic a privilege that was in advance given to French in daily public life, and the spread of Arabic in education and media, which had become crystal in everyday life.

It should be noted in this context that Classical Arabic during colonization was not possible in daily practices; the choice of Arabization and the criteria that accompanied it contributed only to dissemination. In fact, during this period, Arabic had no consideration in the elementary school curriculum, and was not introduced in the secondary school until 1938 as a foreign language, i.e., after 92 years of colonization; that is the imposition of the French language as an instrument of power. Turin (1970) declares :

“Je (Anne Jean Marie Rêne Savary, Duc de Rovigo (1774-1833) commandant en chef en Algérie de (1831-1833) regarde la propagation de l'instruction et de notre langue comme le moyen le plus efficace de faire progrès à notre domination dans ce pays" (p. 40).

(I (Anne Jean Marie Rêne Savary, Duke of Rovigo (1774-1833), Commander-in-chief in Algeria between (1831-1833) see the spread of education, and our language as the most effective means of progressing our domination in this country).

Indeed, the progress of Arabization will not be free from technical, and pedagogical problems (lack of teachers, manuscripts, etc.). Still, these problems were known, and officials were aware of them, and reached to resolve them to find a place for Arabic in a challenge with the French language. Boucherit (1988) asserts in (Le Monde Newspaper): "Il existe une littérature et une presse arabophone, elle ont leur lecteurs, et le marché des journaux arabes est en expansion alors que celui de la presse francophone se réduit au fil des années"'.(p.10).

(There exist Arabic literature and press, it has its readers, and the market of Arabnewspapers is expanding, while that of French language has shrunk over the years).

In this respect, there must be a conception of the results of Arabization and appreciation came up with numerous texts that followed. Worth to mention here that this is not the space to compare between the two languages since there were many factors that decreased the estimated description. An expression like 'The Bilingual Nation' does not absolutely support the discussion. Boucherit (1988) conveys in Le Monde Newspaper, Algérie de l'Arabe à l'Arabisation:

"Il semble néanmoins qu'une expression facile, mais imbécile, comme celle d'analphabète bilingue, que l'on retrouve sous la plume de chercheurs pour désigner les élèves issus du système scolaire algérien, qui ne savait lire ni écrire ni l'arabe standard ni le Français, ne fait guère progresser le débat”. (p.11).

(It seems, however, that an easy, but imbecile expression, like that of a bilingual illiterate, which we find under the pen of researchers to designate students from the Algerian school 
system, who could not read, and write, neither the Standard Arabic, nor the French language, does little to advance the debate).

To note those pupils read and write that language although not as desired. This view is crystal clear through the statistics specified, and which means another time that the rate of education after independence was very low, but it jumped into a high rate at the beginning of 1990s.

"En 1954, 300.000 élèves 'musulmans' sur 2.400.000 élèves en âge d'être scolarisé fréquentaient l'enseignement public, alors le taux d'alphabétisation des adultes est passé de $15 \%$ en 1954 à 58.8\% en 1993 ; à titre de comparaison, pour 1993, il est de 64.1\% en Tunisie et de 41.7\% au Maroc' (GERM. 1997, p. 457).

(In 1954, 300.000 Muslim pupil out of 2.400 .000 pupils of school-age attended public education, so the adult literacy rate had passed from $15 \%$ in 1954 to $58.8 \%$ in 1993 . To compare, for 1993, it was $64.1 \%$ in Tunisia, and $41.7 \%$ in Morocco).

The use of the Arabic language has increased, but this truth did not harm the status of the French language as wished by those who advocated Arabic. This contradiction between the reality and the wishes made the national identity handicapped among the supporters and opponents of Arabization.

Lastly, we can sum up with what Benrabah (2013) affirms:

'After so many years of warring with language, Algerians must make peace with themselves by accepting multilingualism -for a start, by recognizing native Algerian forms of spoken Arabic and Berber as educational building blocks for young children in schools. From that foundation children can go on to learn literary Arabic, French, and perhaps English. As for French, this language certainly lacks the muscle that it enjoyed in Algeria a century ago, so that its future now looks somewhat shaky'. (P.199).

\section{Arabization and the Mother Tongue in the Maghreb}

Arabization from a linguistic point of view consists of changing a foreign language; French, which had taken the status of the official language by a style that can be considered as national; Classical Arabic. To discard that language, Arabic needed to meet daily uses and trades' needs. Put simply; it must be re-adapted to the image of the style that replaced, i.e., French, and which requires profound semiotic and practical alternations. From a sociolinguistic viewpoint, these alternations must put the interest of the social group on the line for those who had a good knowledge of the French language will lose it for the benefit of those who practice Arabic reasonably well. These changes caused tension between the French biases; as a symbol of contemporary modernity, and those advocating Arabic as a source of originality. Then from an anthropolinguistic point of view, it is the Arabization of the cultural law that determines identity through choosing the language and its origin communities, like individuals, can only advance and evolve by relying on their history, recognizing their presence as a true history deeply rooted, but increasingly dynamic form of history. Yet, the development of the modern countries goes beyond this kind of pluralism.

Arab World English Journal for Translation \& Literary Studies 


\section{Language Use and Speech Balance in Algeria}

The linguistic diversity in Algeria is not the result of geographic belonging or social stratification, but it is a matter of history and myths. This view is right hence the land that today constitutes what is called Algeria was previously governed by the Arabs during the $7^{\text {th }}$ century A.D. The Arab's integration with the Berbers, the indigenous tribes of North Africa, represented a serious problem because they had to face those inhabitants in bloody civil wars.

The Algerian linguistic situation has raised important issues concerning the use of Arabic, Tamazight, and French to the extent that whenever the subject of language is raised in Algeria, it is seen and considered as a 'taboo' topic. Algerians, at least the majority, have no crystal-clear view of the linguistic situation as most Algerians reply for; how many languages are there in Algeria, that there are three; Arabic, French, and Tamazight, and they add ' but the national literature is Classical Arabic' Bouhadiba (1998) summarizes this issue when he affirms that:

"...any talk on language variation becomes taboo as soon as this issue is raised. The linguist's say on this matter was virtually nil until recently, were social changes, and political upheavals led to a more objective view on the language issue in Algeria. Thus, when the ordinary man in the street is asked the question: how many languages are there in Algeria, he often says that there is Arabic, French, and Tamazight. He usually adds, but the language of the country is Classical Arabic''. (p.13).

Djaout, (1991) announces: in Le Monde Diplomatique that:

'En 1990 on a vu les langues utilisées en Algérie (Arabe, Berbère, Français) se mettre en quelque sorte en compétitions, en autres à la faveur des publications des nouveaux partis politiques. Incontestablement, le Français sort "vainqueur" de cette confrontation ; cela prouve que l'usage du Français est beaucoup plus important que ce que le pouvoir voulait laisser croire. D'ailleurs les tirages des journaux francophones, qui sont trois plus élevés que ceux des arabophones, en sont une preuve supplémentaire-. (p. 27-8)-

(In 1990, we noted that languages in use in Algeria (Arabic, Berber, and French) are competing, among others, in favor of other new political parties. Unquestionably, French came out the "winner" of this confrontation; this proves that French language use is much more widespread than the government wanted us to believe. Besides, the circulation figures of the francophone newspapers, which are three times as high as those of the Arabophone ones, are another proof of that).

Surprisingly authentic, the Algerian constitutions (1963, 1976, 1989, 1996, 2004, and 2016) stipulated that the Arabic language is the national and official language of the country. But the use of French in Algerian society is worthwhile to conflict quarrel. The existence of French stretches back to the $19^{\text {th }}$ century when France colonized Algeria in 1830. Although French is considered as a foreign language, unlike Tamazight, it remains a competitor to Arabic and is given many privileges within many sectors. Benguida (2017) states in this respect, "It is estimated that some $67 \%$ of the total population have some knowledge of French'. (p.13). Arabic, Tamazight, 
and French are complex findings inside the Algerian society, albeit the historical decision taken just after independence in 1962 to establish Arabic as a national and official language.

\section{Algeria: Language, Nation, and Country}

The emergence of the language problem and the development of the nation made from Algeria a fertile field for study. Algeria suffered from long attacks in its language and culture compared to any other Arab country for more than 132 years of cultural colonialism and educational policies determined by external forces, which profoundly affected the Algerian society. Saad claims (1992):

'The fact that France's domination of Algeria occurred at a time when its linguistic unification was still underway had profound implications for Algeria's linguistic situation. Before the military conquest of Algeria was achieved, the colonial authorities implemented language policies that proved detrimental to Arabic language competence and status'. (p: 21).

Although now Algeria is independent; language remains a point of conflict disputed in political debates.-Holt (1994) points out: "... the more widespread use of Arabic in nationalist and Islamist movements as a source of authenticity and identity"' (p.37). This use of language is the same for most movements across the world, but it has a special significance for the case of Arabic as the language of the Quran; Minogue (1967) argues ' ... it is the nationalist theory desires to discover a past that will support the aspirations of the present. In other words, this is the stage of legend-making'. (p.13).

\section{Conclusion}

The Supreme Council of Arabic language tried to answer the issue of which language do Algerians speak in the $21^{\text {st }}$ century on the occasion of a study day entitled 'The Arabic Language and the Hybrid Languages: Causes and Solutions.' One single issue that is for granted is that the Algerian does not speak classical Arabic, but a kind of creole which is mixed with Arabic, Berber, and French. The process of preparing for this language is achieved at the expense of Arabic. i.e. The Algerians speak incomprehensible Arabic. This issue is well deputized if we come to know that Algerians speak two minutes in French, thirty seconds in Arabic then one minute in French, and so forth.

The writer comes to a summative conclusion regarding the conflicting linguistic situation in Algeria, confirming that AA is a kind of "polluted Arabic" featured by frozen and alien expressions that could not be understood by any Arab, but Algerians. To mean at the end, it is a variety of Arabic which is influenced by all historical periods; from Berber, Turkish, Spanish, Arabic, and French. AA is a language of all ages that stepped Algeria.

In a nutshell, the author considers the Algerian linguistic conflict as an unscathed repercussion from the long colonial experience, and that the French language must be seen as a plus, and that diversity must not only be tolerated, but also encouraged without any ulterior motive of assimilation and accumulation. Further thorough investigations on the quest of language 
independence in Algeria, chiefly with such diversification, will be the subject-matter of an exhaustive study.

\section{About the Author:}

Abdelhamid Bessaid is an Assistant Professor of Sociolinguistics at the department of English/ College of Foreign Languages and Translation, King Khalid University, Abha, KSA. He worked at African University, Adrar, Algeria from 2005 to 2014. His scope of interest is language planning and policy, Sociolinguistic matters in the Arab World, and ESP.

ID ORCID: http://orcid.org/0000-0003-4665-4280

\section{References}

Benguida, K. 2017. Sociolinguistic Dimensions of Code Switching. (Unpublished Doctoral Thesis). Tlemcen Univesity

Benrabah, M. (2013). Language Conflict in Algeria: From Colonialism to Post-Independence. Bristol: Multilingual Matters.

Benrabah, M. (2007). Language -In-Education Planning In Algeria: Historical Development and Current Issues. Language Policy. 6, 225-252. Springer. DOI, 10.1007/s10993-007-9046-7.

Bouhadiba, F. (1998). Le Français d'Algérie ou le Français en Algérie, Enjeux et Perspectives du FLE en Algérie. Revue Didactique des Langues, Oran. Algeria.

Boucherit, A. (October 9, 1988). Algérie de l'Arabe à 1'Arabization. Le Monde, 54.

De Reynand, P. (1836). Arabic Sociolinguistics Issues and Perspectives. La Conquête de l'Algérie par La France.

De Toccqueville. A. (1847). Rapport sur l'Algérie. Bibliothèque Paul-Emile- Boulet de Quebec à Chicoutimi.

Global Education Reform Movement (GERM) 1997. Retrieved from www.researchgate.net > publication>.

Hobsbawm, E. (1990). Nations and Nationalism since 1780. Cambridge: Cambridge University Press

Hot, M. (1994). Algeria: Language, Nation, and State. Toronto, British Library.

Loyer, B. (2002). Langues Nationales et Régionales: Une Relation Géopolitique. Hérodote, 2(105), 15-37

Patai, R. (1973). The Arab Mind. New York, NY: Charles Scribners' Sons.

Saad, Z. (1992). Language Planning and Policy Attitudes: A Case Study of Arabization in Algeria. Columbia University, U.S.A.

Taleb Ibrahimi, K. (1995). Les Algeriens et Leur Langues. Al Hikma.

Tenguour, H. (1994). Intersignes, Idéologie de l'Enfermement. AbeBooks.com. Bibliothèque Arabe. Routledge, Taylor \& Francis Group. Paris.

Arab World English Journal for Translation \& Literary Studies 